\title{
Changing landscape design for public spaces: a call for tree biodiversity
}

\section{Editorial}

Imagine entering a managed public park in any major urban city. On either side of the street or paved walkway is a symmetrical row of trees; the perfect aesthetic for a perfectly planned landscape design as each tree leafs out, blossoms, or changes color in unison like a well-timed orchestra celebrating the change of seasons. The visitor to the park gazes in wonder at the evenly spaced specimens on either side of the pavement. Popular park trees to line streets in the United States are Acer rubrum (Red Maple), Acer saccharum (Sugar Maple), Quercus virginiana (Live Oak), Platanus occidentalis (Sycamore), or Magnolia grandiflora (Southern Magnolia) (Figure 1).

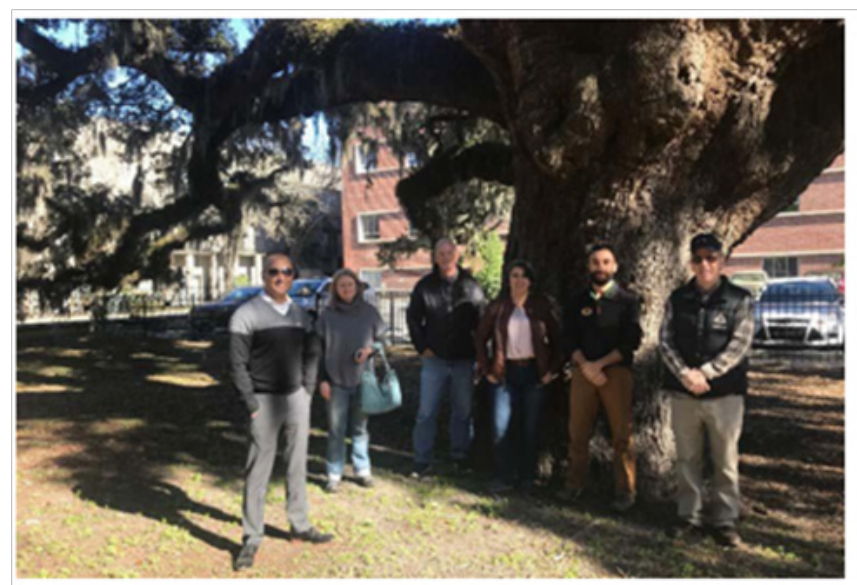

Figure I Arborists \& Foresters from the Southeastern United States standing under the Candler Oak.

All planted at the same time to ensure similar height, size, and shape, all the same scientific family, genus, species, and all susceptible to the same disease, invasive pest, or environmental threat. Public park plantings are lacking in tree biodiversity and our urban green spaces are suffering from hundreds of years of this planned obsolescence. Typically this concept of planned obsolescence is reserved for manufactured objects, but urban green spaces are as much built environments as the buildings adjacent to them. Urban planners and park manager have set their designs up for future failure. Consider the city of Savannah, Georgia, USA, known so much for the consistent plantings of Quercus virginiana (Live Oak) that an outline of the famous Candler Oak, reported to be over 300 years old and the only tree with its own conservation easement in the Southeastern United States, has been incorporated into business advertisements for decades and is the logo for the non-profit Savannah Tree Foundation. Many plantation homes throughout the lowland South featured in movies also feature beautiful live oaks lining the avenue to the front door. But what happens when live oaks become centuries old with roots compacted by pavement, with trunks girdling over curb cuts and storm grates, and low hanging limbs hit by delivery trucks (Figure 2).

One case recorded while conducting a tree inventory for Oconee County, GA discovered over one hundred Platanus occidentalis (Sycamore) lining all of the streets inside Oconee Veterans Park
Volume 3 Issue 2 - 2019

\author{
Allison Joy Bailey \\ Institute for Environmental \& Spatial Analysis, University of \\ North Georgia, Georgia
}

\begin{abstract}
Correspondence: Allison Joy Bailey, Institute for Environmental \& Spatial Analysis, University of North Georgia. Georgia,Tel 470-239-3135, Email allison.bailey@ung.edu
\end{abstract}

Received: February 27, 2019 | Published: March 14, 2019

affected so severely with Anthracnose, a leaf blight, that these ten meter tall trees could not be saved. Early observed symptoms were leaves falling months before the appropriate time of year. A massive cut shocked the community and years of shade and beauty were lost.

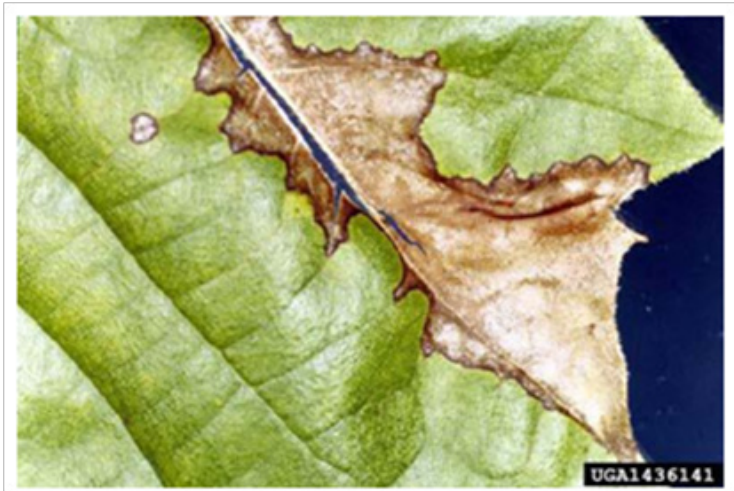

Figure 2 Sycamore anthracnose symptoms on leaf. USDAC operative extension slide series.

Now park managers are concerned about possible threats to the ninety Acer rubrum (Red Maple) and Acer saccharum (Sugar Maple) planted in picnic areas around the park. Common insect threats for which trees can usually recover with treatment: are Maple Leafcutter, Maple Trumpet Skeletonizer, Fall Cankerworm, Fall Webworm, Eastern Tent Caterpillar, to name a few. Invasive insect threats which are more harmful are Asian Longhorned Beetle and Pear Thrips. The most common disease which affects Acer saccharum (Sugar Maple) is Bacterial Leaf Scorch. The United States Forest Service provides up to date information on treating for insects and diseases. Sustainability urban planning committees address concerns for environmental conditions which negatively affect trees in public spaces.

Insects, diseases, and environmental conditions which can potentially harm or kill trees found in public spaces is not the primary problem. Most of these concerns can be addressed with proper tree care and maintenance assuming that the administration has sufficient funds to handle the task at hand. The lack of tree biodiversity in public park plantings presents the problem of losing hundreds of trees in the same season and dramatically reducing the urban tree canopy. Even when park or city managers respond with replanting of young trees, the tree canopy will need decades to return to the cover which existed before the devastation. The primary problem is the landscape design which promote a monoculture over a bio diverse urban landscape. 
Landscape architects and urban planners probably do not even realize that public green spaces are a monoculture when choosing to plant only one tree species in a vista; however, street tree plantings of a single tree species is as much a monoculture as an entire pine or palm oil plantation. Farmers have adjusted tree canopy coverage and increased animal biodiversity by planting other tree species in between agricultural fields. This concept can, and should, be applied to the urban environment. Instead of seeking a symmetrical aesthetic in our public spaces, a call for tree biodiversity is needed. Can humans accept a tree lined street where every other tree is a different species? Where the trees blossom or the leaves change at alternating times in an array of colors? Will we come to see the beauty in tree biodiversity in public spaces? If public spaces do adapt to include tree biodiversity, this will have an impact on the biodiversity of other species in the urban ecosystem as well.

\section{Acknowledgments}

None.

\section{Conflicts of interest}

The author declares that there is no conflicts of interest. 